\title{
Nurses' Knowledge Assessment Regarding Blood Transfusion to Ensure Patient Safety
}

\author{
Asmaa Hamed Abd Elhy ${ }^{1}$,Zeinab Abdel Aziz Kasemy ${ }^{2}$ \\ ${ }^{1}$ lecturer of Medical Surgical Nursing Department-Faculty of Nursing- Menoufia University \\ ${ }^{2}$ lecturer of Public Health , Faculty of Medicine, Menoufia University
}

\begin{abstract}
Blood transfusion has a positive effect on patient life; so nurse play an integral role to maintain patient safety related to blood transfusion.

Aim: This study aimed to assess the level of knowledge regarding blood transfusion among nurses to ensure patient safety.

Setting: This study was conducted in different departments in Menoufia university hospital. Subjects: A convenient sample of 286 nurses from different departments in Menoufia university hospital. Tools: Structure interview schedule: (interview questionnaire sheet) A modified version of the Routine Blood Transfusion Knowledge Questionnaire.

Results: more than half of nurses had poor knowledge regarding to blood transfusion (61.2\%). Also there were statically significant relation between nurses' knowledge and, their characteristic regarding to blood transfusion. Conclusion: The study concluded that deficiency of knowledge among nurses regarding to blood transfusion threaten patient safety, also put patients at life threatening condition.
\end{abstract}

Keywords: blood transfusion, assessment of nurses' knowledge

\section{Introduction}

Blood transfusion is vital and most common therapeutic use in which transfused blood and its component to save patients 'life, Although transfusion enhance patients 'life, it is not without risks ${ }^{(\mathbf{1})}$.Nurses have integral role of blood transfusion if they do it correctly, also nursing practice and safety of transfusion is dependent on nurses' knowledge and skills lead to reduce risk of blood transfusion ${ }^{(2,3)}$

The administration of blood transfusion has five interlocked phases, or stages, four of them related to nursing performance which include preparation before collecting blood units from the storage site, blood bag collection, pre-transfusion activities, and post transfusion activities and monitoring to maintain patients 'safety ${ }^{\mathbf{4}}$, ${ }^{5}$ Preparation of patient prior to blood bag collection in which nurse must check a written prescribe by physician, should provide sufficient information to patients about indication of blood transfusion, its risks and benefits and advantages. Also patent and intravenous set must be available, pre medication and other intravenous solutions should be complete prior to blood transfusion as prescribed ${ }^{(6,7)}$.

Collection of blood pack is important element to enhance patients' safety; the nurse ensure patient's identification details on the collection slip, blood bag, to prevent blood incompatibility .Also blood bags should be transported by special blood transport box ${ }^{(\mathbf{8}) \text {. }}$

Before starting blood transfusion; the nurse must recognized the right and correct patient who intended blood through two approved persons and a three- test out which includes the blood component label, compatibility slip, and wristband of patient, this is the most critical step of transfusion safety and the final opportunity to interrupt any incorrect blood component. ${ }^{(9,10)}$, also British Committee for Standards in Haematology ${ }^{(11)}$ recommended that special filters size must be accessible to reduce bacterial profusion (170-200 micron).

Post transfusion activities ; at the beginning of transfusion, nurse must initiate infusion rate of blood slowly during the first 15 minutes to prevent reactions that is occur during this period ${ }^{(\mathbf{1 2})}$.Also nurse must observe the patient for the first $10-15$ minutes and record vital signs ${ }^{(13)}$. Each transfusion should be completed within four hours from its beginning. Administration of intravenous normal saline and morphine $1.0 \mathrm{mg} / \mathrm{ml}$ is safe solution can use during blood transfusion, other solution or medication not accepted ${ }^{(7)}$. In addition, the nurse should be aware of any signs and symptoms of reaction and how to deal with this condition to save patient life.

Nurses are usually expert on the skills of blood transfusion during their years of experience. However, the level of knowledge varies among health care provider as nurses. A lot of studies have been conducted in other countries to evaluate nurses' knowledge of blood transfusion, while a little studies conducted in Egypt ${ }^{(13) \text {. }}$ .So this study will fill a gap regarding nurses' knowledge and transfusion safety in the clinical setting. 


\section{Significance of the study:}

Flood and Higbie, $2016^{(14)}$ stated that World Health Organization $($ WHO,2011), reported that over nine million patients in 90 different Countries receive blood in a year. According to SHOT program (Serious Hazards of Transfusion) about $70 \%$ of all reported adverse events are recognized to the improper transfused blood component. Moreover, half of these events involve more than one error in the transfusions process

${ }^{(15)}$. Inadequate knowledge about safe blood transfusion practices among nurses can lead to adverse consequences in the transfusion recipients' .So: The nurses must be understood the proper and safe method for blood transfusion practice ${ }^{(\mathbf{1 6})}$.

\section{Aim}

To assess the level of knowledge regarding blood transfusion among nurses to ensure patient safety.

Research question:

Q: What is the nurses' knowledge about blood transfusion to ensure patient safety?

\section{Subjects \& Methods}

To fulfill the aim of this study, the following research question was formulated:

\section{Research design:}

A descriptive exploratory research design was utilized to achieve the purpose of the study and answer the research question.

Setting:

This study was conducted in all (different) departments in Menoufia university hospital.

\section{Subjects:}

A convenient sample of 286 nurses from different department in Menoufia university hospital

Subjects: Health care in the University hospitals is provided by 1100 nurses (Statistical Administrative Records of Hospitals, 2016). The total number of nurses to be selected was estimated using the following equation: $\mathrm{n}=(\mathrm{z} 2 \times \mathrm{p} \times \mathrm{q}) / \mathrm{D} 2$. Since the actual level of knowledge about blood transfusion was unknown, the probability of its occurrence was estimated to be equal to that of its nonoccurrence $(\mathrm{p}=\mathrm{q}=0.5)$ and a value of 0.025 was chosen as the acceptable limit of precision (D). Based on these assumptions, the sample size was estimated to be 286 nurses.

Tool : Structure interview schedule: (interview questionnaire sheet)

A modified version of the Routine Blood Transfusion Knowledge Questionnaire

(RBTKQ) comprising seven sections (43 items) by Hij.ji Oweis, and Dabbour (2012) ${ }^{(4)}$. These are modified by the researcher who deleted section from questionnaire because there was no standardized and accredit issues related to blood transfusion policies and procedures. So 43 items modified to 39 items (7 items of 39 included information about nurses" demographics and training then32 items were classified to five sections. Classified as the following:

Section A: Issues Relating to Patient Preparation which include five questions

Section B: Blood Pack Collection which include three questions

Section C: Pre-Transfusion Initiation Nursing Activities which include sex questions

Section D: Post Transfusion Initiation Nursing Activities and Issues which include ten questions

Section F: Complications Related to Blood Transfusion which include eight questions

\section{Scoring system:-}

Each item was given a score 2 for right responses and make1 for wrong responses, All scores were summed and the total scores were from 32 to 64 . The higher score indicated good knowledge as follow:

The scoring system was categorized as follow:

- Poor knowledge $(<50 \%)$

- Fair knowledge $(50-<75 \%)$

- Good knowledge $(\geq 75 \%)($

Reliability

- Tool was tested; Chronbach alpha was 0.95. It was 0.95

Field work:

Data collection for this study was carried out from the first November 2016 to January,2017. Once permission was granted to conduct the study, the researchers were initiated collection.

Pilot Study 
Pilot study was conducted on 30 nurses to test the clarity and applicability of the data collection. A pilot study was carried out on $10 \%$ of study sample (30nurses) from different departments of hospital to test feasibility and applicability of tool and modifications were done therefore. Data obtained from the pilot study was excluded from the actual study.

\section{Ethical considerations}

An official permission to conduct the study was obtained from the responsible authorities after explaining the aim of the study. Formal consent was obtained from each participant. Voluntary participation, anonymity, and confidentiality were all guaranteed.

\section{Data collection}

Before data collection the researchers distributed the questionnaire to the study group that agrees to share in the study and explain the objective of the study to the participants. The average time taken for completing questionnaires was around 20-30 minutes. After completion of the questionnaires, the researchers collect it and make sure that questionnaires sheet was being filled completely.

\section{Statistical analysis}

Results were statistically analyzed by SPSS version 20 . Chi-Squared $(\chi 2)$ was used for qualitative variables. Pearson's Correlation analysis was used to show strength and direction of association between two quantitative variables. $P$ value $<0.05$ is considered significant.

\section{Result}

Table 1: Distribution of the nurses regarding their demographic data:

\begin{tabular}{|c|c|c|}
\hline & $\mathrm{N}=286$ & $\%$ \\
\hline $\begin{array}{l}\text { Age } \\
<25 \\
25-30 \\
>30\end{array}$ & $\begin{array}{c}39 \\
89 \\
158\end{array}$ & $\begin{array}{l}13.6 \\
31.1 \\
55.2\end{array}$ \\
\hline $\begin{array}{l}\text { Sex } \\
\text { Male } \\
\text { Female }\end{array}$ & $\begin{array}{c}24 \\
262\end{array}$ & $\begin{array}{l}24.0 \\
76.0\end{array}$ \\
\hline $\begin{array}{l}\text { Education } \\
\text { Secondary } \\
\text { Institute } \\
\text { College } \\
\text { Post }\end{array}$ & $\begin{array}{c}48 \\
115 \\
120 \\
3\end{array}$ & $\begin{array}{r}16.8 \\
40.2 \\
42.0 \\
1.0\end{array}$ \\
\hline $\begin{array}{l}\text { Experience in years } \\
\leq 1 \\
>1-3 \\
>3-5 \\
>5\end{array}$ & $\begin{array}{c}28 \\
53 \\
38 \\
167\end{array}$ & $\begin{array}{c}9.8 \\
18.5 \\
13.3 \\
58.4\end{array}$ \\
\hline $\begin{array}{l}\text { Over the past } 6 \text { months, } \\
\text { Number of blood transfusion } \\
\text { Non } \\
1-4 \\
5-8 \\
9-12 \\
>12\end{array}$ & $\begin{array}{l}90 \\
61 \\
31 \\
52 \\
52\end{array}$ & $\begin{array}{l}31.5 \\
21.3 \\
10.8 \\
18.2 \\
18.2\end{array}$ \\
\hline $\begin{array}{l}\text { Share in program of blood } \\
\text { transfusion } \\
\text { No } \\
\text { Yes }\end{array}$ & $\begin{array}{c}249 \\
37\end{array}$ & $\begin{array}{l}87.1 \\
12.9\end{array}$ \\
\hline
\end{tabular}

Table (1) illustrated that more than half of studied sample at the age above 30 year old (55.2\%), above two third of theses sample were female (76\%). almost half $(42 \%)$ was Bachelor degree in nursing. More than half of studied sample had experience more than five years; also one third of them hadn't perform number of blood transfusion(31.5\%), most of studied sample were not share of any program of blood transfusion( $87.1 \%)$ 
Table 2: Number and percentage distribution of nurses' knowledge regarding blood transfusion

\begin{tabular}{|l|l|c|c|}
\hline \multicolumn{2}{|c|}{ Knowledge scores } & \multicolumn{2}{c|}{$(\mathbf{n = 2 8 6})$} \\
\cline { 3 - 4 } Issues Relating to Patient & Poor & 51 & $\%$ \\
Preparation & Fair & 205 & 17.8 \\
& Good & 30 & 71.7 \\
\multirow{3}{*}{ Blood Pack Collection } & Poor & 129 & 10.5 \\
\hline \multirow{2}{*}{ Pre-Transfusion Initiation } & Fair & 110 & 45.1 \\
Nursing Activities & Good & 47 & 38.5 \\
& Poor & 268 & 16.4 \\
\hline \multirow{2}{*}{ Post Transfusion Initiation } & Fair & 16 & 93.7 \\
Nursing Activities And Issues & Good & 2 & 5.6 \\
& Poor & 176 & 0.7 \\
\hline \multirow{2}{*}{ Complications Related to } & Fair & 109 & 61.5 \\
Blood Transfusion & Good & 1 & 38.1 \\
& Poor & 204 & 0.3 \\
\hline \multirow{2}{*}{ Total } & Fair & 80 & 71.3 \\
& Good & 2 & 28.0 \\
\end{tabular}

Table (2) showed that more than two third of studied sample had fair knowledge toward Issues Relating to Patient Preparation(71.7\%), while (45.1\%) had poor knowledge regarding to Blood pack collection, also most of studied sample hadn't knowledge related to Pre-transfusion initiation nursing activities(93.7\%).More than third of them had fair knowledge about post transfusion initiation nursing activities and issues $(38.1 \%)$, but the majority of sample had poor knowledge regarding to complication related to blood transfusion $(71.3 \%)$.

Table 3: Relation between nurses' knowledge and their characteristic regarding to blood transfusion

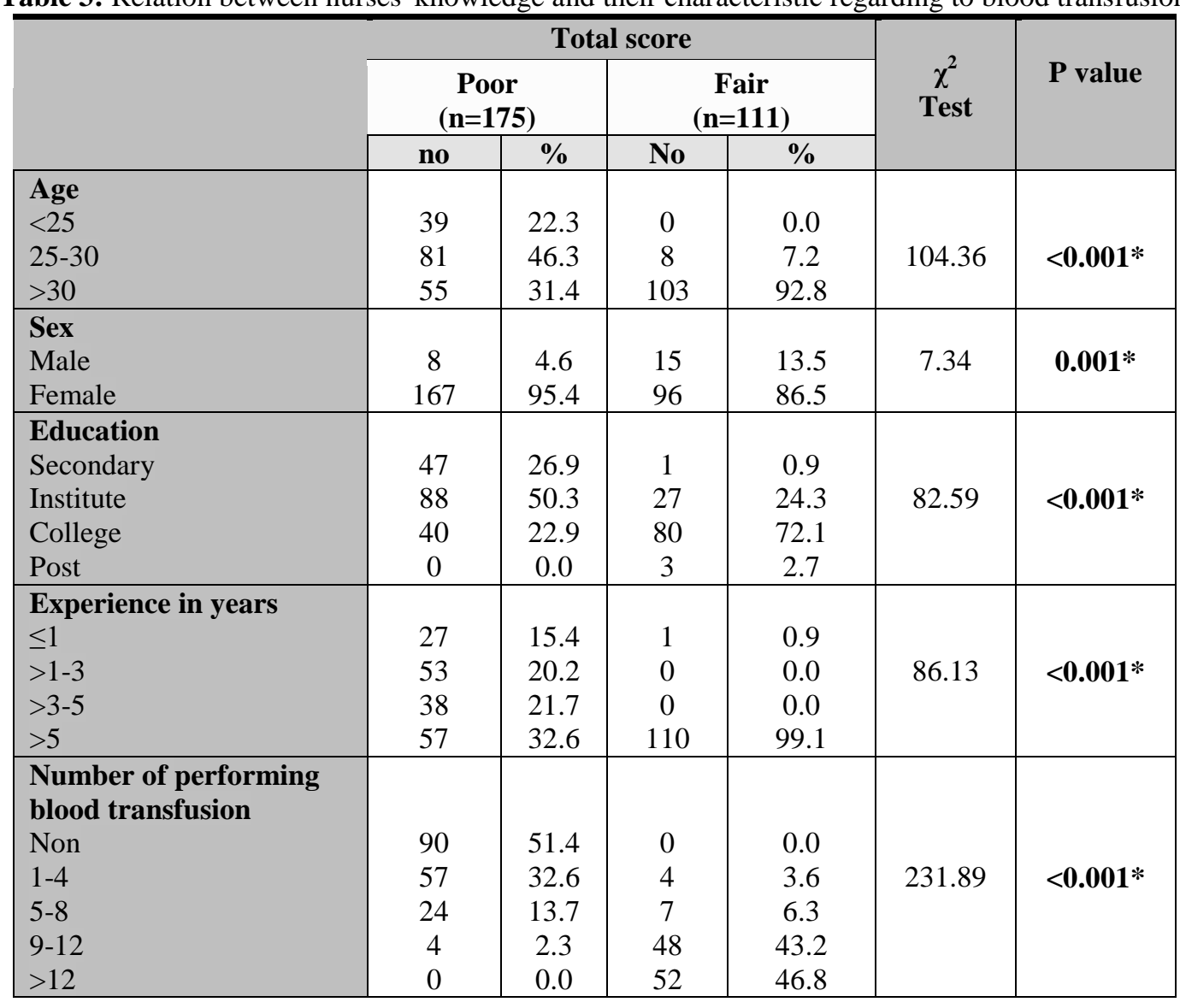




\begin{tabular}{|l|c|c|c|c|c|c|}
\hline $\begin{array}{l}\text { Share in program of } \\
\text { blood transfusion }\end{array}$ & 175 & 100.0 & 74 & 33.7 & 67.0 & $<\mathbf{0 . 0 0 1 *}$ \\
No & 0 & 0.0 & 37 & 33.3 & & \\
Yes
\end{tabular}

Table(3) showed that there were statically significant difference related to age ,sex, level of education, experience, number of performing blood transfusion and share in program regarding to blood transfusion $\mathrm{P}(<0.001 *)$

Table 4: Correlation between different knowledge scores regarding to process of blood transfusion

\begin{tabular}{|c|c|c|c|c|c|c|c|c|c|c|}
\hline \multirow[t]{2}{*}{ Variable } & \multicolumn{2}{|c|}{$\begin{array}{l}\text { A. Issues } \\
\text { Relating to Patient } \\
\text { Preparation }\end{array}$} & \multicolumn{2}{|c|}{$\begin{array}{l}\text { B } \\
\text { Blood Pack } \\
\text { Collection }\end{array}$} & \multicolumn{2}{|c|}{\begin{tabular}{l}
\multicolumn{1}{c}{ C } \\
\multicolumn{1}{c}{ Pre- } \\
Transfusion \\
Initiation \\
Nursing \\
Activities \\
\end{tabular}} & \multicolumn{2}{|c|}{$\begin{array}{c}\text { D } \\
\text { post Transfusion } \\
\text { Initiation Nursing } \\
\text { Activities And } \\
\text { Issues }\end{array}$} & \multicolumn{2}{|c|}{\begin{tabular}{l}
\multicolumn{1}{c}{ E } \\
Complications \\
Related to Blood \\
Transfusion
\end{tabular}} \\
\hline & $r$ & $P$ value & $r$ & $P$ value & $\mathrm{r}$ & $\begin{array}{c}\mathrm{P} \\
\text { value }\end{array}$ & $r$ & $\begin{array}{c}P \\
\text { value }\end{array}$ & $r$ & $\begin{array}{c}\mathrm{P} \\
\text { value }\end{array}$ \\
\hline $\begin{array}{l}\text { A } \\
\text { Issues Relating to } \\
\text { Patient Preparation }\end{array}$ & - & - & 0.299 & $<0.001^{*}$ & 0.193 & $\begin{array}{c}\mathbf{0 . 0 0 1} \\
*\end{array}$ & 0.168 & 0.004* & 0.290 & $\begin{array}{c}<0.001 \\
*\end{array}$ \\
\hline $\begin{array}{c}\text { B } \\
\text { Blood Pack } \\
\text { Collection }\end{array}$ & - & - & - & - & 0.075 & 0.206 & 0.343 & $\underset{*}{<0.001}$ & 0.382 & $\underset{*}{<0.001}$ \\
\hline $\begin{array}{c}\text { C } \\
\text { Pre-Transfusion } \\
\text { Initiation Nursing } \\
\text { Activities } \\
\end{array}$ & - & - & - & - & - & - & 0.020 & 0.740 & 0.127 & 0.032 \\
\hline $\begin{array}{c}\text { D } \\
\text { post Transfusion } \\
\text { Initiation Nursing } \\
\text { Activities And } \\
\text { Issues } \\
\end{array}$ & - & - & - & - & - & - & - & - & 0.483 & $\begin{array}{c}<0.001 \\
*\end{array}$ \\
\hline $\begin{array}{c}\mathrm{E} \\
\text { Complications } \\
\text { Related to Blood } \\
\text { Transfusion }\end{array}$ & - & - & - & - & - & - & - & - & - & - \\
\hline
\end{tabular}

*significant

Table (4): found that there were statically significant positive relationship between nurses' knowledge regarding issues relating to patient preparation and blood pack collection, Pre-Transfusion Initiation Nursing Activities ,post transfusion initiation nursing activities and issues, Complications Related to Blood Transfusion, $\mathrm{p}$ value $\left(<0.001^{*},<0.001,0.004^{*},\left(<0.001^{*}\right)\right.$ respectively. While there was no significant relation blood pack collection and pre-transfusion initiation nursing activities

\section{Discussion}

Nurse play an integral role regarding to blood transfusion ,also nurse must have adequate knowledge to all process of transfusion to maintain patient 'safety. The current study showed the majority of studied sample were female, almost of them were BSc in nursing. This result was in the same line with Silva, et al (2016) ${ }^{(17)}$ who stated that more than two thirds of studied sample were female that have Bachelor degree in nursing. The present study illustrated that most of participant did not receive any training program, This result was in the same line with Ahamed, 2011) ${ }^{(\mathbf{1 8})}$ who found that the majority of nurses did not join any preceding teaching program about blood transfusion

The present study illuminated that more than half of studied sample had poor knowledge regarding to all steps of blood transfusion, In agreement with present study Tavares, et al.,(2015) ${ }^{(19)}$, who found nurses' knowledge deficiency regarding to all steps of blood transfusion. In addition Diakité, Diawara, and Tchogang, $2012{ }^{(20)}$, who found that about half of participants had insufficient knowledge related to blood transfusion. Also this result was consistent with Kabinda, et al., 2014 ${ }^{(21)}$ who clarified that because of lack of continuous and regular training in blood transfusion result in insufficient knowledge among nursing staff about principle of blood safety. Researchers explained that inadequate educational program provided to nurse to refresh nurse's knowledge lead to these result.

Regarding to blood transfusion, the present study showed that the majority of studied sample had adequate knowledge related to preparation of patient prior to blood transfusion such as checking patency of intravenous access line, recording baseline vital signs, information given to patient, bring blood from bank 
should not take place before the administration of any prescribed pre-medication, decisions to be taken by the nurse with incomplete order or ensure that informed consent has been obtained.), this result was in the same line with Tetteh, 2015 ${ }^{\text {(22) }}$ who found that nurses' had excellent Knowledge related to patient preparation about blood transfusion .In addition to Yaghoobi, et al.,2014 ${ }^{(23)}$, who mentioned that more than half of studied sample had a good knowledge before blood transfusion

The current study showed more than half of studied sample had fair and good knowledge related to blood pack collection, (which include method used to transport blood from blood bank, Knowledge of basic $\mathrm{ABO}$ terminology, Information to ensure collecting the right blood from blood bank).This result was in the same line with Lee, Rahim, and Din,2016 ${ }^{(13)}$, who stated that about half of these studied sample had adequate knowledge about blood pack collection

The present study illustrated that most of studied sample had poor knowledge regarding to Pretransfusion initiation nursing activities as (Patient identification, indications for blood warming, best time to start the transfusion, steps for patient identification, suitable filter size of transfusion set), this result was agreement with Hijji ,Oweis,and Dabbour $2012{ }^{(4)}$ who found that the majority of participant had inadequate knowledge about nursing responsibility before starting the blood transfusion. In addition, Saillour-Glenisson, et al., 2002 ${ }^{\text {(24) }}$ who found that participant in his study had low level knowledge on blood transfusion regarding to patients 'identification. The researchers clarified that patient identification consider the foundation to prevent mistake,error from blood transfusion; so insufficient knowledge put patient at risk

The present study stated that two thirds of participant had poor knowledge related to nursing responsibility post blood transfusion as (activities routinely performed by nurses after starting the blood transfusion., the Maximum duration of using a blood administration set for continuous multiple transfusions, maximum duration for completing a unit of blood, agents compatible with blood, vital signs recording after starting a transfusion )this result was in agreement with Khalil, et al.,2013 ${ }^{(\mathbf{1})}$ who revealed that insufficient level of knowledge about blood, blood transfusion and complications of blood transfusion, which reveals the lack in their scientific training. In addition to ${ }^{(\mathbf{1 3})}$, who found that about one third of participant didn't recognize time for measuring vital signs post initiate blood transfusion.

The present study found that the majority of sample had poor knowledge regarding to complication related to blood transfusion this finding as the same line with Silva, et al., $\mathbf{2 0 0 9}^{(25)}$ who observed that more than two thirds of studied sample had inadequate knowledge and care related to blood complication, however this result in contrast with Yaghoobi, et al.,2014 ${ }^{(23)}$, who explained that most of studied sample had adequate knowledge related to complication. From the researchers' point of view, this discrepancy may be due to nurses learning through experience how to deal with blood transfusion reactions and colleagues who provide the same care. Also, inadequate education and training program and inadequate refreshment of knowledge periodically lead to poor nurse' knowledge which put patients at risk during, post blood transfusion

The present study revealed that there were statistically significant difference related to knowledge score and demographic data and sample characteristic, this result was consistent with Lee, Rahim, and Din,2016 ${ }^{(13)}$ who found significant relations between socio demographic character as age, years of service with total knowledge scores.

The present study revealed that participant who had experience more than five years had good knowledge (significant relation between years of experience and total knowledge score this result coincided with Masoud ,2006 (26) who found that there was significant relation between knowledge and years of experience. In contrast with the present study Betty, Devi, \& Kanakalakshmi $2016^{(27)}$ who found that there was no significant difference between, educational level and or presence to educational program before, The researcher clarified that with increasing age, years of working and experience, the person can learn more and more or own a lot of knowledge

Regarding to level of education, the present study showed that high level of education had adequate knowledge, also significant difference than other level of education, this result was in line with Mwamwenda ,2014 ${ }^{\text {(28) }}$, who mentioned that there was relationship between level of education and knowledge score. The researcher explained this difference as the nurses who attended educational program have chance to discuss with other qualified person and learn more.

The present study showed, there were positive correlation between items or steps of blood transfusion, while there was no significant relation between blood pack collection and pre-transfusion initiation nursing activities this result in contrast with Hijji, Oweis, and Dabbour, 2012 and Stevenson \& Wood ${ }^{(4,29)}$ who clarified that the transfusion process is composed of five correlated and linked stage ; four of them are clarified significant routine nursing practice which related to patient blood bag collection, pre and post blood transfusion activities , preparation before blood bag collection, blood pack collection, pre and post transfusion nursing activities.

In addition to Odham $\mathbf{J}$ et $\mathbf{a l}, 2009^{(30)}$ who mentioned that nurse has the main role in every step of blood transfusion process to prevent error and complication from transfusion, so maintain patients 'safety. The 
researcher clarified that because the nurse is under many burdens at work so do not seek to gain any information and depend only on what nurse learn from practice, so there was no significant correlation between some items of blood transfusion process

Finally, the researchers clarified that without basic information about each step of blood transfusion and the important of each one related to each other, patient will be in threat life from complication; so the nurse must have an excellent knowledge to promote safety

Conclusion: The study concluded that deficiency of knowledge among nurses regarding to blood transfusion threaten patient safety, also put patients at life threatening condition. Recommendation: Educational and training program are essential for all staff to improve nurses' knowledge.

\section{Reference}

[1]. Khalil,S,. Mohammad,Z., Ez El-Deen.,M, And Ahmed,N . Blood Transfusion. Impact Of Implementing A Designed Nursing Intervention Protocol On Nurses' Knowledge And Practice Regarding Patients Undergoing Blood Transfusion .Med. J. Cairo Univ.2013;81(2) 163-71.available at: Www.Medicaljournalofcairouniversity.Net

[2]. Al Nasr,M, (2016).Assessment Of Nurses' Performance Regarding Nursing Care Of Patients Undergoing Blood Transfusion Published Thesis. Port Said-University. Faculty Of Nursing

[3]. Aslani,Y, Etemadyfar,S, And Noryan,K. Nurses' Knowledge Of Blood Transfusion In Medical Training Centers Of Shahrekord University Of Medical Science (2010); 15(3):141-44. available at: Www.SID.Ir

[4]. Hijji, B, Oweis, A, Dabbour, R. Measuring Knowledge Of Blood Transfusion: A Survey Of Jordanian Nurses. American International Journal Of Contemporary Research.2012;2(10) available at: Www.Aijcrnet.Com /retrieved on 10-2016

[5]. Bielby, L. Stevenson \& E. Wood.(2011). The Role Of The Transfusion Nurse In The Hospital And Blood Center. International Society Of Blood Transfusion, ISBT Science Series 2011; 6, 270-6

[6]. Saxena, S., Ramer, L. And Shulman, I. (2004). A Comprehensive Assessment Program To Improve Blood-Administering Practices Using The FOCUS-PDCA Model (2004). Transfusion, 44, 1350-56.

[7]. Mcclelland D (2007). Pre Transfusion And Transfusion Procedures .Handbook Of Transfusion Medicine. 4th Edition. London: TSO.20-21.Http://Host.Bglot.Com/BATM/BATM2016/

[8]. Taylor, C.(2010) , Cohen, H., Mold, D., Jones, H., Et Al., On Behalf Of The Serious Hazards Of Transfusion (SHOT) Steering Group. (2010). The2009 Annual SHOT Report. Retrieved From Http://Www.Shotuk.Org/Wpcontent/ Uploads/2010/07/SHOT2009.Pdf

[9]. bsy MA, Saxena S, Nelson J, Et Al(2007). Safe Handling And Administration Of Blood Components: Review Of Practical Concepts. Arch Pathol Lab Med 2007 May;131(5):690-4.

[10]. Dzik W. New Technology For Transfusion Safety. BJH Review 2006 Nov;136:181-90 / In 2010 Pennsylvania Patient Safety Authority. 2010; 7(2)

[11]. British Committee For Standards In Haematology (2012a) Guideline On The Administration Of Blood Components Addendum, London: BCSH. available at: Www.Bcshguidelines.Com

[12]. Janatpour, K.; Kalmin, N.; Jensen, H. And Holland, P. (2008). Clinical Outcomes Of ABO-Incompatible RBC Transfusions.American Journal Of Clinical Pathology. Am J Clin Pathol. 2008;129(2):276-281.

[13]. Lee,E, Rahim,N, Tuan Din,S (2016). Knowledge Of Blood Transfusion Among Nurses At Hospital Pulau Pinang: Nursing Responsibilities And Patient Management Related To Transfusion Reactions. Education In Medicine Journal. 2016; 8(4): 47-56 47

[14]. Flood,L And Higbie J(2016) .A Comparative Assessment Of Nursing Students' Cognitive Knowledge Of Blood Transfusion Using Lecture And Simulation. Nurse Educationinpractice16(2016)8e13. available at: Www.Elsevier.Com/Nepr22-11-2016

[15]. Gray A, Illingworth J. (2005). Right Blood, Right Patient, Right Time. RCN Guidance For Improving Transfusion Practice. Royal College Of Nursing, London, UK

[16]. Www.Inernationaljournalofcaringscienes.Org 22-11-2016

[17]. Friedman 2011) MT: Blood Transfusion Practices: A Little Consistency Please. Blood Transfus 2011;9:362-365).

[18]. Silva,K, Floriano,D, Duarte,R, Tavares,J, Félix,M, Silva,Q, Andrade,L Ferreira,L, Barichello,E, And Barbosa,M. Blood Transfusion In Cancer Patients: Knowledge Of The Nursing Team. 2016; 9(1). 341

[19]. hamed, G.H.(2011).Effect Of Designed Nursing Protocol On Nurse's Knowledge And Practice Regarding Hemodialysis Patients. Published Thesis Submitted For Partial Fulfillment Of Master Degree In Medical And Surgical Nursing Faculty Of Nursing,Assiut University, 2011.

[20]. Tavares JL, Barichello E, De Mattia AL,Barbosa MH.(2015). Factors Associated With Knowledge Of The Nursing Staff At A Teaching Hospital On Blood Transfusion. Rev Lat Am Enfermagem. 2015;23:595-602. available at: Https://Doi.Org/10.1590/01041169.0024.2593./7-1-2017

[21]. Diakité M, Diawara SI, Tchogang NT. Knowledge And Attitudes Of Medical Personnel In Blood Transfusion In Bamako, Mali.Transfus Clin Biol. 2012; 19(2): 74-77.

[22]. Kabinda,J, Miyanga,S, Donnen,P, Ende,V And Dramaix,M .2014.Knowledge, Attitudes And Practices Of Medical And Paramedical Staff In Blood Transfusion In The Democratic Republic Of Congo. Open Journal Of Preventive Medicine, 2014, 4, $672-680$

[23]. Published Online August 2014 In Scires. Http://Www.Scirp.Org/Journal/Ojpm

[24]. Tetteh, E (2015). Knowledge And Practice Of Blood Transfusion Among Nurses In Ghana : EXPERIENCES FROM THE CAPE COAST TEACHING HOSPITAL, CAPE COAST . Thesis Submitted To The School Of Nursing And Midwifery Of College Of Health And Allied Sciences, University Of Cape Coast, In Partial Fulfillment Of The Requirements For The Award Of Master Of Nursing Degree Nurses' Excellent Knowledge On Patient Preparation Activities.

[25]. Yaghoobi, M, Shirzaie,Kianoosh, Sotvaan, Homa,Yaghoobi Pheyzabad, Esmat, Yoosefian Miandoab, Nazanin. Knowledge Level Of The Staff's About Blood Transfusions In Hospitals In East Of Iran/ Year: $2014 ; 02$ ( 01) . 91-96/Science Road Journal.

[26]. Saillour-Glenisson F, Tricaud S, Mathoulin-Pelissier S, Bouchon B, Galperine I, Fialon P, Et Al. Factors Associated With Nurses' Poor Knowledge And Practice Of Transfusion Safety Procedures In Aquitaine, France. Int J Qual Health Care. 2002;14(1):25-32. [Pubmed) 
[27]. Silva MA, Torres GV, Melo GSM, Costa IKF, Tiburcio MP, Farias,TYA. Conhecimento Acerca Do Processo Transfusional Da Equipe.De Enfermagem Da UTI De Um Hospital Universitário. Ciênc. Cuid.Saúde [Internet]. 2009 Out/Dez [Cited 2016 Fev 10]; 8(4): 571 .578- available at: Http://Periodicos.Uem.Br/Ojs/Index.Php/Cienccuidsaude/Article/View/9676/5389

[28]. Masoud S.E.(2006). The Impact Of Educational And Training Program On The Knowledge And Performance Of Nursing Practice In The Hematology And Emergency Unites At: Pediatric Department Of Assiut University Hospital. Published Thesis For Doctorate Degree In Pediatric Nursing.

[29]. Betty,L.G, Devi,C, \& Kanakalakshmi R(2016)..Assess The Knowledge Regarding Blood Transfusion Among Staff Nurses And Nursing Students In NMCH, Nellore. International Journal Of Applied Research 2016; 2(4): 226-230 .Available At Http://Www.Allresearchjournal.Com22-112016

[30]. Mwamwenda,T(2014). Education Level And (HIV/AIDS Knowledge In Kenya. Journal Of AIDS And HIV Research. Vol. 6(2), Pp. 28-32, February, 2014. SSN 2141 -2359 2014 Academic Journals. available at: Http://Www.Academicjournals.Org/JAHR

[31]. Stevenson, B \& Wood, E. 2011. The Role Of The Transfusion Nurse In The Hospital And Blood Centre. International Society Of Blood Transfusion, ISBT Science Series (2011) 6, 270-276

[32]. Odham J Et Al. Right Patient, Right Blood, Right Care: Safe Transfusion Practice. British Journal Of Nursing. 2009; Vol-18(5): Page 312,314,316-320. IN Devi,Y.,(2009). A Descriptive Study To Assess The Knowledge And Practice Regarding Blood Transfusion Among The Nurse In Selected Cardiac Hospital. Published Dissertation. 